\title{
Which Personal Protective Equipment Should I Use while Caring for Children Attending the ED? Paediatric Emergency Procedures in the COVID-19 Era and Beyond
}

Simon Craig ( $\nabla$ Simon.craig@monash.edu )

Monash University

Julia Clark

Queensland Children's Hospital

Mike Starr

Royal Children's Hospital

Joanne Grindlay

Royal Children's Hospital

Andrew Tagg

Sunshine Hospital, Western Health

Jim Buttery

Monash University

Meredith L Borland

Perth Children's Hospital

Ed Oakley

Royal Children's Hospital

Viet Tran

University of Tasmania

Jamie Lew

Canberra Hospital

Fiona Thomson

Queensland Children's Hospital

David Krieser

Sunshine Hospital, Western Health

Jason Hort

Children's Hospital Westmead, Sydney Children's Hospital Network

Amit Kochar

Women's and Children's Hospital

Benjamin Lawton

Logan Hospital 


\section{Asha Bowen}

Perth Children's Hospital

\section{Brendan McMullan}

Monash Health

Jason Acworth

Queensland Children's Hospital

\section{Pamela Palasanthiran}

Sydney Children's Hospitals Network

\section{Emma Best}

Starship Children's Health

\section{Lesley Voss}

Starship Children's Health

\section{Stuart Dalziel}

Starship Children's Health

\section{Research Article}

Keywords: personal protective equipment (PPE), paediatric procedures, acute respiratory illness.

Posted Date: July 1st, 2021

DOI: https://doi.org/10.21203/rs.3.rs-565729/v1

License: (c) (1) This work is licensed under a Creative Commons Attribution 4.0 International License. Read Full License 


\section{Abstract}

Objectives

To determine recommendations for the use of personal protective equipment (PPE) based on transmission risk for paediatric procedures in the Emergency Department during the COVID-19 pandemic.

Methods

Two survey rounds were conducted in April-May 2020. The survey presented a number of emergency medicine procedures relevant to the care of children, and asked respondents to provide PPE recommendations according to levels of community transmission, and whether or not the child had symptoms of acute respiratory illness.

Results

Participants were recruited by approaching relevant professional groups, with 15 from the PREDICT network and 12 from the Australasian Society of Infectious Diseases (ASID) Paediatric Infectious Diseases (ANZPID) Group.

Airborne PPE is recommended for resuscitative procedures and various respiratory procedures in most situations There were differences in opinion between emergency and paediatric infectious disease specialists with regards to most appropriate PPE for children without symptoms of COVID-19 in a setting of low community transmission, and for procedures involving the head, neck or airway. In general, emergency physicians were more likely to favour airborne PPE than infectious disease specialists. In the setting of high community transmission, there was a stronger tendency to recommend at least droplet precautions for most procedures - regardless of whether or not the child had symptoms.

Conclusions

Differences in PPE recommendations for various paediatric procedures between infectious disease specialists and emergency physicians were identified. Further research is urgently needed to clarify and quantify risks for many common interventions and determine strategies for multidisciplinary consensus regarding future recommendations.

\section{Introduction}

The global pandemic of coronavirus disease 2019 (COVID-19) continues to create significant disruption, with social and economic upheaval in many countries, mass job losses, local and nationwide shutdowns, and prolonged school closures.

Experience from previous infectious disease outbreaks - notably that of Severe Acute Respiratory Syndrome (SARS) in 2003 - suggests that healthcare workers (HCWs) are at considerable risk, 
particularly when involved in critical care procedures. ${ }^{1-3}$ The crisis has, for the first time in many countries, put front-line clinicians "in harm's way". Healthcare workers can potentially acquire the illness from patients, families, and from close proximity to colleagues. Feelings of personal vulnerability are exacerbated by reports of shortages of personal protective equipment (PPE), fatalities of HCWs in other countries, ${ }^{45}$ and poor prior knowledge of appropriate infection control practices.

Emergency Department (ED) clinicians are not experts in infection control. Despite long-standing risks of occupational exposure to various infections such as influenza, varicella, measles, Neisseria meningitidis and tuberculosis, they are often poor performers in audits of hand hygiene. ${ }^{6}$ Further, PPE use may not be prioritised when faced with a rapidly deteriorating patient requiring urgent resuscitation.

An additional concern for emergency practitioners is the difficulty distinguishing COVID-19 infection from the frequent and relatively low-risk presentations of other common childhood viral illnesses. ${ }^{7}$ These children, likely to be indistinguishable from those with other common viral illnesses, may still present an infectious risk to the HCW in both the ED and primary care setting. Further, although we are currently focused on COVID-19, similar precautions are also necessary for influenza, which disproportionately affects children compared to adults.

Faced with a global pandemic, suboptimal baseline knowledge of appropriate infection control procedures, and the potential for relatively well children to harbour a pathogen capable of causing serious illness to themselves and their care providers, ED clinicians are understandably concerned for their own safety. On the other hand, potential and actual shortages, practicality, comfort and ease of use, require that use of PPE be appropriate and rational. In this context, it is important to provide clear infection control guidance for when children are seen or when procedures are performed on children in the ED, based upon the best available information.

\section{Important definitions relating to healthcare acquired infections}

Viral illness and upper respiratory tract infections are commonly recorded ED diagnoses in major paediatric centres. ${ }^{8}$ Droplet and contact transmission are considered usual modes of spread, with droplet transmission typical for most respiratory viral illnesses though airborne transmission is recognised in certain circumstances. (Table 1). 
Table 1

Differences between droplet and airborne transmission, and recommended PPE

\begin{tabular}{|c|c|c|}
\hline & Droplet transmission & Airborne transmission \\
\hline $\begin{array}{l}\text { Potential } \\
\text { source }\end{array}$ & $\begin{array}{l}\text { Sneezing, coughing, } \\
\text { spitting result in } \\
\text { droplets usually }>5 \\
\text { microns in size. }\end{array}$ & $\begin{array}{l}\text { "Aerosol-generating procedures" (AGPS) such as } \\
\text { intubation and non-invasive ventilation result in smaller } \\
\text { droplets which remain suspended in the air for a longer } \\
\text { period of time }\end{array}$ \\
\hline \multirow[t]{3}{*}{ Transmission } & $\begin{array}{l}\text { Contact with } \\
\text { conjunctiva and } \\
\text { mucosa }\end{array}$ & Inhalation of aerosols \\
\hline & $\begin{array}{l}\text { Contact via hands on } \\
\text { a surface where } \\
\text { droplets have } \\
\text { deposited }\end{array}$ & \\
\hline & $\begin{array}{l}\text { Droplet and contact } \\
\text { PPE }\end{array}$ & Airborne and contact PPE \\
\hline \multirow[t]{3}{*}{ Similarities } & Gown / Apron & Gown / Apron \\
\hline & Non-sterile gloves & Non-sterile gloves \\
\hline & Eye protection* & Eye protection \\
\hline \multirow[t]{3}{*}{ Differences } & Surgical mask & N95/P2 mask (also known as N95 respirator) \\
\hline & - Loose-fitting & - Close facial fit; forms a seal around nose and mouth \\
\hline & $\begin{array}{l}\text { - Physical barrier } \\
\text { between nose and } \\
\text { mouth and immediate } \\
\text { surroundings }\end{array}$ & - Physical barrier and filtration of small particles \\
\hline
\end{tabular}

In addition to hand hygiene, the use of droplet and contact PPE reduces the risk of transmission, as it provides a physical barrier between the droplets and the portal of entry, ${ }^{9}$ and is recommended in most settings for prevention of transmission of SARS CoV-2. ${ }^{10}$

Airborne transmission may be associated with the generation of aerosols during specific procedures such as intubation and non-invasive ventilation. These aerosol-generating procedures (AGPs) may result in an infectious aerosol; ${ }^{11}$ some aerosols may also be released by coughing, sneezing or shouting - these have been termed "aerosol-generating behaviours". Available evidence indicates the maximum transmission distance of SARS-Cov-2 may be about 4 metres. ${ }^{12}$ However, these aerosols can be inhaled by HCWs in the immediate path of the aerosol and lead to infection. 
Although there is ongoing debate, ${ }^{13}$ it is assumed that similar risks for SARS CoV-2 transmission exist during the performance of AGPs, and in order to prevent inhalation of small particles, airborne and contact PPE (gown, N95 or P2 mask, gloves and eye protection) is recommended.

\section{Which procedures are considered aerosol generating procedures?}

It is therefore important to determine which paediatric procedures pose an airborne virus transmission risk to HCWs. However, this is far from straightforward, and due to the difficulty and time required to accumulate high-quality evidence, consensus-based recommendations might be useful to gauge expert opinion and inform interim practice.

\section{Aims}

At the initial phase of the COVID-19 pandemic, we set out to determine- from emergency physicians and infectious disease specialists - recommendations for the use of PPE based on transmission risk for paediatric ED procedures.

\section{Methods}

An expert group of 15 emergency physicians was recruited from hospitals associated with the Paediatric Research in Emergency Departments International Collaborative (PREDICT) Network. A second group of 12 experts was recruited by approaching the Australasian Society of Infectious Diseases (ASID) Paediatric Infectious Diseases (ANZPID) Group.

Members of each group were sent an electronic survey asking them to consider a list of procedures and to make a recommendation for PPE use (airborne PPE, droplet PPE, or standard precautions) in each of the following scenarios:

(1) Current [April 2020 - May 2020] situation in Australia and New Zealand (NZ) (low levels of community transmission, plenty of ICU capacity)

(a) A child unwell with respiratory symptoms and/or fever

(b) A child with NO respiratory symptoms and NO fever

(2) Possible future (out of control) situation in Australia and NZ (high levels of community transmission, limited or minimal ICU capacity)

(a) A child unwell with respiratory symptoms and/or fever

(b) A child with NO respiratory symptoms and NO fever

We pre-specified a "consensus" recommendation being achieved if $80 \%$ of respondents from one group chose the same option. For those where consensus was not reached after the first survey, a second survey was distributed, providing an overview of the responses to the first round. If $80 \%$ of more 
respondents agreed on the second round, this was accepted as consensus. If between $50 \%$ and $80 \%$ of respondents chose a particular option, this was accepted as a weak ("low consensus") recommendation. If none of the options were selected by at least $50 \%$ of respondents after two survey rounds, no consensus was recorded.

Surveys were distributed to each group independently and analysed by specialty (i.e. emergency medicine vs infectious diseases). The first round of surveys was distributed to emergency physicians in early April and to infectious diseases specialists in late April 2020, with subsequent surveys distributed two weeks later. The project was deemed exempt from HREC review as a quality assurance project by Monash Health Research Office (RES-20-0000423Q -65895).

\section{Results}

All fifteen emergency physicians responded to both rounds of the survey. Of the twelve infectious diseases physicians who responded to the first round, ten (83\%) responded to the second round. Responses relating to the April-May 2020 situation (low levels of community transmission) are presented in Tables 2 and 3, while responses relating to a possible future situation (high levels of community transmission) are presented in Tables 4 and 5.

In the setting of low community transmission, airborne PPE was recommended for resuscitative procedures (such as cardiopulmonary resuscitation (CPR), intubation) and respiratory procedures (nebuliser therapy, non-invasive ventilation, suctioning) in children with respiratory symptoms or fever. However, in the setting of a child without respiratory symptoms or fever, emergency physicians recommended airborne PPE, while infectious diseases physicians recommended droplet PPE (Table 2).

There was less agreement between emergency physicians and infectious diseases physicians when asked about other procedures involving the head, neck or airway (e.g. throat examination, removal of a nasal foreign body, insertion of a nasogastric tube). In symptomatic children, emergency physicians were more likely to recommend airborne PPE while infectious diseases physicians recommended droplet PPE, while in asymptomatic children, infectious diseases physicians were more likely to recommend no specific precautions (Table 3).

For all other paediatric emergency procedures, there was broad agreement for the use of droplet precautions in symptomatic patients, with the exception of sedation and/or physical restraint for acute behavioural disturbance. For asymptomatic patients, infectious diseases physicians were more likely to recommend standard precautions, while emergency physicians preferred droplet precautions for a number of procedures (Table 3 ).

In what was, at the time, a hypothetical future situation with high levels of community transmission, there was broad agreement for airborne PPE for resuscitative and respiratory procedures (Table 4), some differences of opinion for procedures involving the head, neck and airway, with emergency physicians more likely to recommend airborne PPE than infectious diseases physicians, and broad support for 
droplet PPE for most other paediatric emergency procedures, with the exception of the management of acute behavioural disturbance (Table 5).

\section{Discussion}

The COVID-19 pandemic has challenged health systems worldwide. Concerns have been raised about guidance on PPE being driven by lack of available stock, rather than research evidence. ${ }^{14}$ On the other hand, some authorities have asserted that "procedures on screaming children" are an AGP ${ }^{15}$ and require the same precautions as intubation.

Our study has confirmed ongoing uncertainty. Based on two rounds of surveys conducted early in the pandemic in Australia and New Zealand, there were differences of opinion between those working in emergency medicine, and those working in infectious diseases. Emergency physicians were more comfortable recommending airborne PPE for a wider range of procedures and clinical situations than their infectious disease physician colleagues. In the absence of clear evidence, it is likely that differences in perceived personal risk contributed to this disparity; fear of contracting the virus and/or transmitting it to loved ones has been documented as a real concern. ${ }^{16} 17$ On the other hand, ID physicians are likely to have a more complete understanding of community transmission, and specialised knowledge in PPE, infection precautions, and infection control / outbreak management for other pathogens.

Most studies of AGPs have been analyses of nosocomial infections in the adult setting, ${ }^{18}$ laboratory experiments using mannequins to simulate coughing, ${ }^{11}{ }^{19}$ or studies of aerosols in healthy human volunteers. ${ }^{20}$ It is important to note that AGPs are a heterogeneous group of activities and do not all carry the same risk of aerosol generation and transmission. Based on research conducted during the 2003 SARS epidemic, the only AGP consistently associated with SARS CoV- 1 transmission to date is intubation $^{4,18}$ and thus procedures associated with intubation such as $\mathrm{CPR}^{2}{ }^{2}$ pre-intubation suctioning ${ }^{3}$ non-invasive ventilation, ${ }^{18}$ and manual ventilation prior to intubation. ${ }^{18}$ are now generally accepted to be associated with higher risk for virus transmission. Limited data are available that directly apply to the paediatric setting.

However, there is active debate and ongoing research regarding the extent to which resuscitative procedures are considered AGPs. At the time of writing, defibrillation alone is not considered an AGP, with a recent International Liaison Committee on Resuscitation (ILCOR) systematic review finding no evidence that defibrillation generates aerosols. ${ }^{21}$ Compression-only CPR has recently been assessed by the United Kingdom (UK) New and Emerging Respiratory Virus Threats Advisory Group ${ }^{22}$ and the Australian Department of Health, ${ }^{23}$ and is not considered an AGP by either body. ILCOR suggests - through a weak recommendation based on very low certainty evidence - that chest compressions have the potential to generate aerosols. ${ }^{21}$ Whilst these recommendations are important for adult resuscitations, paediatric resuscitation is almost always a result of hypoxia and requires different responses and likely higher 
exposure to the airway of a child, Whilst this is the case, there is limited evidence to guide paediatricians in these circumstances.

Nebulisation has been associated with infection transmission in one study, ${ }^{1}$ but no association was found in another. ${ }^{18}$ Current UK recommendations for COVID-19 suggest that nebulisation is low risk, as aerosols are generated by the equipment rather than the patient. ${ }^{24}$ However, Australian guidelines recommend against the use of nebulised agents for the treatment of non-intubated COVID-19 patients. ${ }^{25}$ A recent study on a healthy human adult volunteer demonstrated high levels of aerosols with the use of non-invasive ventilation and nebulisation, ${ }^{20}$ but low levels of aerosol generation with high-flow oxygen therapy, which is currently classified as an AGP. Further work is needed to identify whether these risks are the same for children.

On the other hand, the large numbers of healthcare worker (HCW) infections in Australia (and overseas) from a variety of settings, and ongoing transmission events in Australia's hotel quaratntine program, suggests that COVID-19 infection in adults poses a significant occupational risk. PPE advice during the recent second wave of COVID-19 in Victoria, Australia has been criticised for being "haphazard, incremental and inconsistently applied" outside intensive care settings. ${ }^{26}$ With increased discussion of possible airborne transmission, there has, in recent months, been a call to apply the precautionary principle and recommend higher level protection for $\mathrm{HCWs}^{27}$

However, given children are less likely to acquire COVID-19 or develop severe disease ${ }^{28}$ and seem less likely to be implicated in community transmission, ${ }^{29}$ it is unsurprising that occupational acquisition of $\mathrm{HCW}$ from children is so far unreported. Risk of occupational exposure cannot be extrapolated from adults to children.

Differences in knowledge and opinion between various specialties providing care for patients in the COVID-19 pandemic have emerged as areas of friction. Our work highlights the challenges in developing, implementing and framing evidence-based guidance for prevention of occupational exposure in the context of an emerging pathogen, particularly in children where infection and transmission dynamics appear different from those in adults and evidence to inform practice is absent. In the absence of clear evidence, it is likely that emergency physician responses were somewhat influenced by anxiety regarding the possibility of acquiring COVID-19 at work, however, PPE recommendations need be acceptable to those who consider themselves "in harm's way". Working together across specialties, sharing experiences across hospitals, regions and countries and conducting collaborative research to answer these questions are high priorities for future work.

In the months since the survey was circulated, there has been a gradual shift towards acceptance of the possibility of airborne transmission outside traditional AGPs. ${ }^{30}$ Expert groups at the national and international have been increasingly engaging input from multiple clinical disciplines. 
Local PPE recommendations are currently based upon epidemiological risk factors (travel, contact with a COVID-19 patient, community prevalence) as well as potential risks of AGPs and/or aerosol-generating behaviours. ${ }^{31}$ As such, they are less able to be directly compared to the PPE recommendations developed by our survey.

\section{Limitations}

There is minimal paediatric evidence available. More information is urgently needed, and should incorporate recent scientific models of respiratory pathogen transmission. ${ }^{32}$ related specifically to children and viral viability. However, this type of expert consensus has been the "real world" experience for hospital policy development and pandemic management with novel emergent pathogens.

Responses from emergency physicians were acquired 2-3 weeks earlier than those from infectious diseases specialists. This may have led to differences of opinion based upon increasing infection-control advice and falling rates of community transmission in Australia and New Zealand at the time ID physicians were surveyed, variation in community transmission, concerns about adequate stocks of PPE, and perceived personal risks of nosocomial transmission. In addition, the responses shown here reflect opinions during a time prior to substantial community and health care worker infections in Victoria, Australia and it is possible that opinions may have changed since the surveys were conducted.

We need to better understand disease transmission, be prepared, trained and willing to correctly use PPE on a daily basis for many patients, and ensure rational use of PPE. Whilst there are emerging studies already investigating environmental and air contamination with SARS-CoV2 using PCR technology, there are few data investigating the viability of the virus on contaminated surfaces.

Epidemiological studies comparing rates of HCW infections between regions with different approaches to PPE use would also be of interest. Further technological and engineering advances to minimise the generation of potentially infective aerosols are also needed.

\section{Conclusion}

The COVID-19 crisis has highlighted the importance of occupational transmission of respiratory pathogens. The same mechanisms for COVID-19 transmission exist with routine respiratory viruses in children. Enhanced PPE use based on this pandemic will further protect the workforce from nosocomial infection risk, with training in use of PPE and engagement of staff in personal protection ongoing high priorities.. Increased understanding of the possibility of airborne transmission is balanced against very low community prevalence in Australia and New Zealand. The differences in opinion between infectious disease specialists and emergency physicians regarding PPE recommendations for various paediatric procedures during a pandemic are concerning, and highlight the need for multidisciplinary input into PPE guidance. Further research is urgently needed to clarify and quantify risks as well as to promote multidisciplinary communication and evidence-based consensus for many common interventions. 


\section{Declarations}

\section{Ethics approval and consent to participate}

All methods were carried out in accordance with relevant guidelines and regulations. This was a survey, and did not involve any randomisation or experimentation. All survey participants were informed regarding the nature and purpose of the study and consented to participate.

\section{Consent for publication}

All authors reviewed the manuscript and gave approval for submission.

\section{Availability of data and materials}

All data generated or analysed during this study are included in this published article [and its supplementary information files].

\section{Competing interests}

$\mathrm{SC}$ is an editorial board member of BMC Pediatrics.

\section{Funding}

Not applicable

\section{Authors' contributions}

The study was conceived by SC, AB and SD. All authors contributed to data collection and interpretation, and reviewed the manuscript and gave approval for submission.

\section{Acknowledgments}

Not applicable

\section{References}

1. Chan-Yeung M. Severe acute respiratory syndrome (SARS) and healthcare workers. Int J Occup Environ Health 2004;10(4):421-7. doi: 10.1179/oeh.2004.10.4.421 [published Online First: 2005/02/11]

2. Christian MD, Loutfy M, McDonald LC, et al. Possible SARS coronavirus transmission during cardiopulmonary resuscitation. Emerg Infect Dis 2004;10(2):287-93. doi: 10.3201/eid1002.030700

3. Loeb M, McGeer A, Henry B, et al. SARS among critical care nurses, Toronto. Emerg Infect Dis 2004;10(2):251-55. doi: 10.3201/eid1002.030838

4. Wang J, Zhou M, Liu F. Exploring the reasons for healthcare workers infected with novel coronavirus disease 2019 (COVID-19) in China. Journal of Hospital Infection doi: 10.1016/j.jhin.2020.03.002 
5. Zhan M, Qin Y, Xue X, et al. Death from Covid-19 of 23 Health Care Workers in China. N Engl J Med 2020;382(23):2267-68. doi: 10.1056/NEJMc2005696 [published Online First: 2020/04/16]

6. Seo HJ, Sohng KY, Chang SO, et al. Interventions to improve hand hygiene compliance in emergency departments: a systematic review. Journal of Hospital Infection 2019;102(4):394-406. doi:

10.1016/j.jhin.2019.03.013

7. Dong Y, Mo X, Hu Y, et al. Epidemiological Characteristics of 2143 Pediatric Patients With 2019 Coronavirus Disease in China. Pediatrics 2020:e20200702. doi: 10.1542/peds.2020-0702

8. Acworth J, Babl F, Borland M, et al. Patterns of presentation to the Australian and New Zealand Paediatric Emergency Research Network. Emergency medicine Australasia : EMA 2009;21(1):59-66. doi: 10.1111/j.1742-6723.2009.01154.x [published Online First: 2009/03/04]

9. Siegel JD, Rhinehart E, Jackson M, Chiarello L, and the Healthcare Infection Control Practices Advisory Committee, 2007 Guideline for Isolation Precautions: Preventing Transmission of Infectious Agents in Healthcare Settings https://www.cdc.gov/infectioncontrol/guidelines/isolation/index.html.

10. World Health Organization. (2020). Rational use of personal protective equipment for coronavirus disease (COVID-19): interim guidance, 27 February 2020. World Health Organization. https://apps.who.int/iris/handle/10665/331215. .

11. Davies A, Thomson G, Walker J, et al. A review of the risks and disease transmission associated with aerosol generating medical procedures. Journal of Infection Prevention 2009;10(4):122-26. doi:

$10.1177 / 1757177409106456$

12. Guo ZD, Wang ZY, Zhang SF, et al. Aerosol and Surface Distribution of Severe Acute Respiratory Syndrome Coronavirus 2 in Hospital Wards, Wuhan, China, 2020. Emerg Infect Dis 2020;26(7):1583-91. doi: 10.3201/eid2607.200885 [published Online First: 2020/04/11]

13. Morawska L, Milton DK. It is Time to Address Airborne Transmission of COVID-19. Clin Infect Dis 2020 doi: 10.1093/cid/ciaa939 [published Online First: 2020/07/07]

14. O'Sullivan ED. PPE guidance for covid-19: be honest about resource shortages. Bmj 2020;369:m1507. doi: 10.1136/bmj.m1507 [published Online First: 2020/04/19]

15. Australian and New Zealand Intensive Care Society (2020) ANZICS COVID-19 Guidelines. Version 2. Melbourne: ANZICS . Available from: https://www.anzics.com.au/coronavirus-guidelines/ Accessed 12th June 2020.

16. Shanafelt T, Ripp J, Trockel M. Understanding and Addressing Sources of Anxiety Among Health Care Professionals During the COVID-19 Pandemic. Jama 2020 doi: 10.1001/jama.2020.5893 [published Online First: 2020/04/08] 
17. O'Neal HRJ, Lin JC, Devlin JW, et al. Coronavirus Disease 2019: Harnessing Healthy Fear via Knowledge, Attitudes, and Behavior. Critical Care Explorations 2020;2(6):e0149. doi:

$10.1097 /$ cce. 0000000000000149

18. Tran K, Cimon K, Severn M, et al. Aerosol generating procedures and risk of transmission of acute respiratory infections to healthcare workers: a systematic review. PLoS One 2012;7(4):e35797. doi: 10.1371/journal.pone.0035797 [published Online First: 2012/05/09]

19. Judson SD, Munster VJ. Nosocomial Transmission of Emerging Viruses via Aerosol-Generating Medical Procedures. Viruses 2019;11(10):940. doi: 10.3390/v11100940

20. McGain F, Humphries RS, Lee JH, et al. Aerosol generation related to respiratory interventions and the effectiveness of a personal ventilation hood. Crit Care Resusc 2020 [published Online First: 2020/06/02]

21. International Liaison Committee on Resuscitation. COVID-19: Practical Guidance for Implementtation [Internet]. April 2020. Available from https://www.ilcor.org/covid-19. Accessed 15 April 2020.

22. Public Health England. PHE statement regarding NERVTAG review and consensus on cardiopulmonary resuscitation as an aerosol generating procedure (AGP). 27 April 2020. Online. Avaialble from https://www.gov.uk/government/publications/wuhan-novel-coronavirus-infection-prevention-andcontrol/phe-statement-regarding-nervtag-review-and-consensus-on-cardiopulmonary-resuscitation-as-anaerosol-generating-procedure-agp Accessed 3rd May 2020.

23. Department of Health. Guidance on the use of personal protective equipment (PPE) in hospitals during the COVID-19 outbreak. Australian Government, Department of Health. April 27th 2020. Available fromhttps://www.health.gov.au/resources/publications/guidance-on-the-use-of-personal-protectiveequipment-ppe-in-hospitals-during-the-covid-19-outbreak; accessed 5th May 2020.

24. COVID-19: Guidance for infection prevention and control in healthcare settings. Version 1. March 2020. Department of Health and Social Care (DHSC), Public Health Wales (PHW), Public Health Agency (PHA) Northern Ireland, Health Protection Scotland (HPS) and Public Health England. Accessed 26th March 2020 [online]. Available from: https://www.gov.uk/government/publications/wuhan-novelcoronavirus-infection-prevention-and-control.

25. Australian and New Zealand Intensive Care Society (2020) ANZICS COVID-19 Guidelines). Melbourne: ANZICS. Accessed 26th March 2020 [online]. Available from: https://www.anzics.com.au/coronavirusguidelines/.

26. Ananda-Rajah M VB, Miller A, Heslop D. Health care worker safety has fallen short of best practice. MJA Insight [Online resource; 28 September 2020; Accessed 29 September 2020; available from https://insightplus.mja.com.au/2020/38/health-care-worker-safety-has-fallen-short-of-best-practice/ MJA Insight. 
27. Maclntyre CR, Wang Q. Physical distancing, face masks, and eye protection for prevention of COVID19. The Lancet 2020;395(10242):1950-51. doi: 10.1016/S0140-6736(20)31183-1

28. Castagnoli R, Votto M, Licari A, et al. Severe Acute Respiratory Syndrome Coronavirus 2 (SARS-CoV-2) Infection in Children and Adolescents: A Systematic Review. JAMA Pediatrics 2020;174(9):882-89. doi: 10.1001/jamapediatrics.2020.1467

29. Li X, Xu W, Dozier M, et al. The role of children in transmission of SARS-CoV-2: A rapid review. J Glob Health 2020;10(1):011101-01. doi: 10.7189/jogh.10.011101

30. Greenhalgh T, Jimenez JL, Prather KA, et al. Ten scientific reasons in support of airborne transmission of SARS-CoV-2. Lancet 2021 doi: 10.1016/s0140-6736(21)00869-2 [published Online First: 2021/04/19]

31. Department of Health. Guidance on the minimum recommendations for the use of personal protective equipment (PPE) in hospitals during the COVID-19 outbreak. Australian Government. Deaprtment of Health. 9 November 2020. Available from: https://www.health.gov.au/sites/default/files/documents/2020/11/guidance-on-the-use-ofpersonal-protective-equipment-ppe-in-hospitals-during-the-covid-19-outbreak.pdf. Accessed 30th April 2021.

32. Bourouiba L. Turbulent Gas Clouds and Respiratory Pathogen Emissions: Potential Implications for Reducing Transmission of COVID-19. JAMA 2020 doi: 10.1001/jama.2020.4756

\section{Tables}

Table 2. Expert group PPE recommendations for resuscitation / respiratory support: current situation with low levels of community transmission 


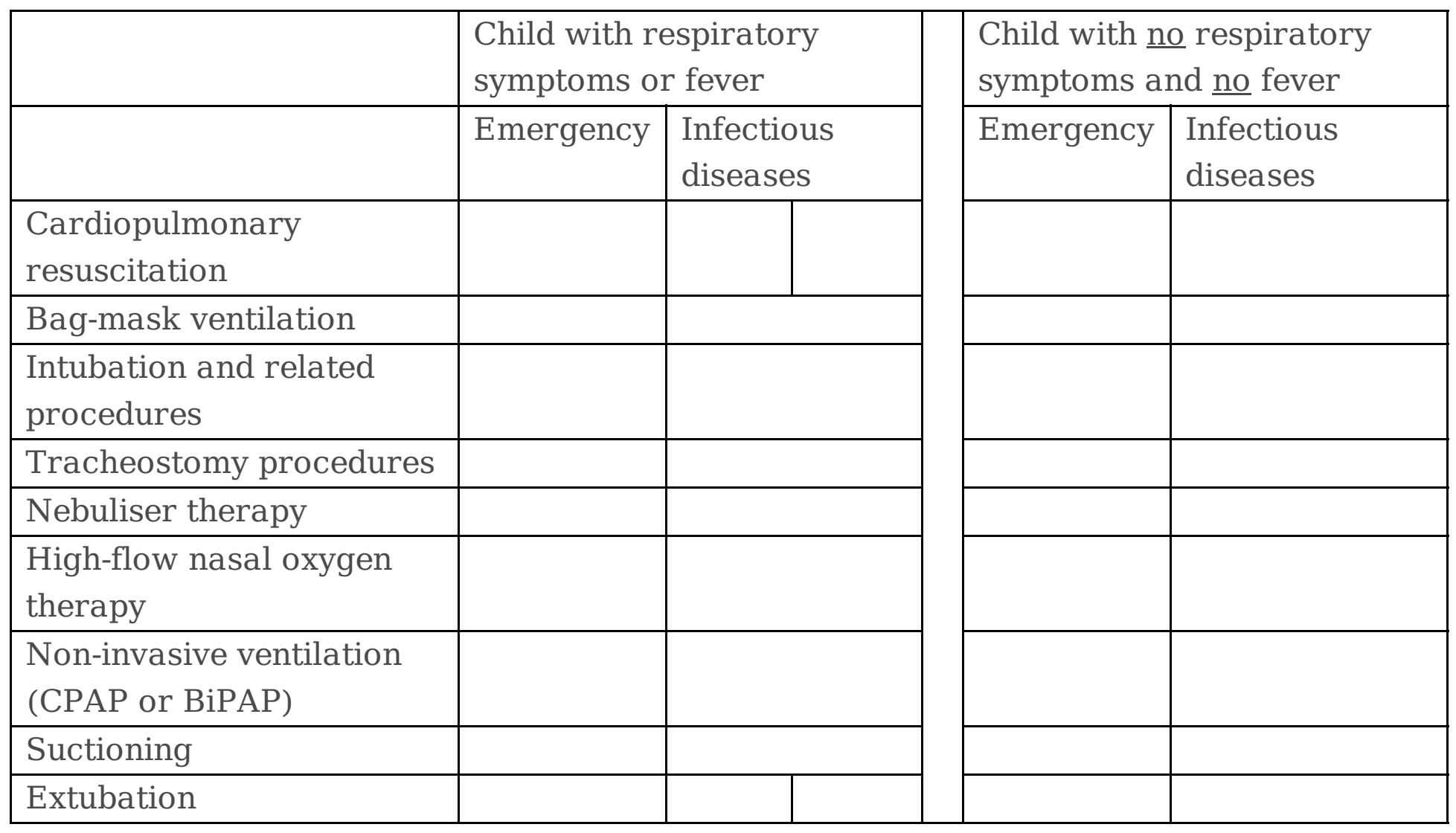

Key:

\begin{tabular}{|c|c|}
\hline Airborne PPE (consensus) & Standard precautions (consensus) \\
\hline Airborne PPE (low consensus) & Standard precautions (low consensus) \\
\hline Droplet PPE (consensus) & No consensus \\
\hline Droplet PPE (low consensus) & Two equal recommendations \\
\hline
\end{tabular}

Table 3. Expert group PPE recommendations for other procedures involving the head / neck / airway, and other paediatric emergency procedures: current situation with low levels of community transmission 


\begin{tabular}{|c|c|c|c|c|c|}
\hline & & \multicolumn{2}{|c|}{$\begin{array}{l}\text { Child with respiratory } \\
\text { symptoms or fever }\end{array}$} & \multicolumn{2}{|c|}{$\begin{array}{l}\text { Child with no } \\
\text { respiratory symptoms } \\
\text { and no fever }\end{array}$} \\
\hline & & Emergency & $\begin{array}{l}\text { Infectious } \\
\text { diseases }\end{array}$ & Emergency & $\begin{array}{l}\text { Infectious } \\
\text { diseases }\end{array}$ \\
\hline \multirow{11}{*}{$\begin{array}{l}\text { Head, neck } \\
\text { and airway } \\
\text { procedures }\end{array}$} & Throat examination & & & & \\
\hline & Nasal / throat swab & & & & \\
\hline & $\begin{array}{l}\text { Nasopharyngeal } \\
\text { aspirate }\end{array}$ & & & & \\
\hline & $\begin{array}{l}\text { Removal of nasal } \\
\text { foreign body in a } \\
\text { child }\end{array}$ & & & & \\
\hline & $\begin{array}{l}\text { Continuous flow } \\
\text { nitrous oxide } \\
\text { delivered by mask in } \\
\text { an uncooperative } \\
\text { small child }\end{array}$ & & & & \\
\hline & $\begin{array}{l}\text { Nitrous oxide } \\
\text { delivered by a } \\
\text { patient-demand } \\
\text { system }\end{array}$ & & & & \\
\hline & Eye examination & & & & \\
\hline & Ear examination & & & & \\
\hline & $\begin{array}{l}\text { Inhaled } \\
\text { bronchodilators via } \\
\text { puffer and spacer in } \\
\text { small / } \\
\text { uncooperative child }\end{array}$ & & & & \\
\hline & $\begin{array}{l}\text { Nasogastric tube } \\
\text { insertion in small / } \\
\text { uncooperative child }\end{array}$ & & & & \\
\hline & $\begin{array}{l}\text { Intranasal } \\
\text { medication } \\
\text { administration (e.g. } \\
\text { fentanyl) }\end{array}$ & & & & \\
\hline \multirow{3}{*}{$\begin{array}{c}\text { Other } \\
\text { paediatric } \\
\text { emergency } \\
\text { procedures }\end{array}$} & $\begin{array}{l}\text { Examination of a } \\
\text { cooperative child }\end{array}$ & & & & \\
\hline & $\begin{array}{l}\text { Examination of an } \\
\text { uncooperative child }\end{array}$ & & & & \\
\hline & \multicolumn{5}{|c|}{ Page $16 / 20$} \\
\hline
\end{tabular}




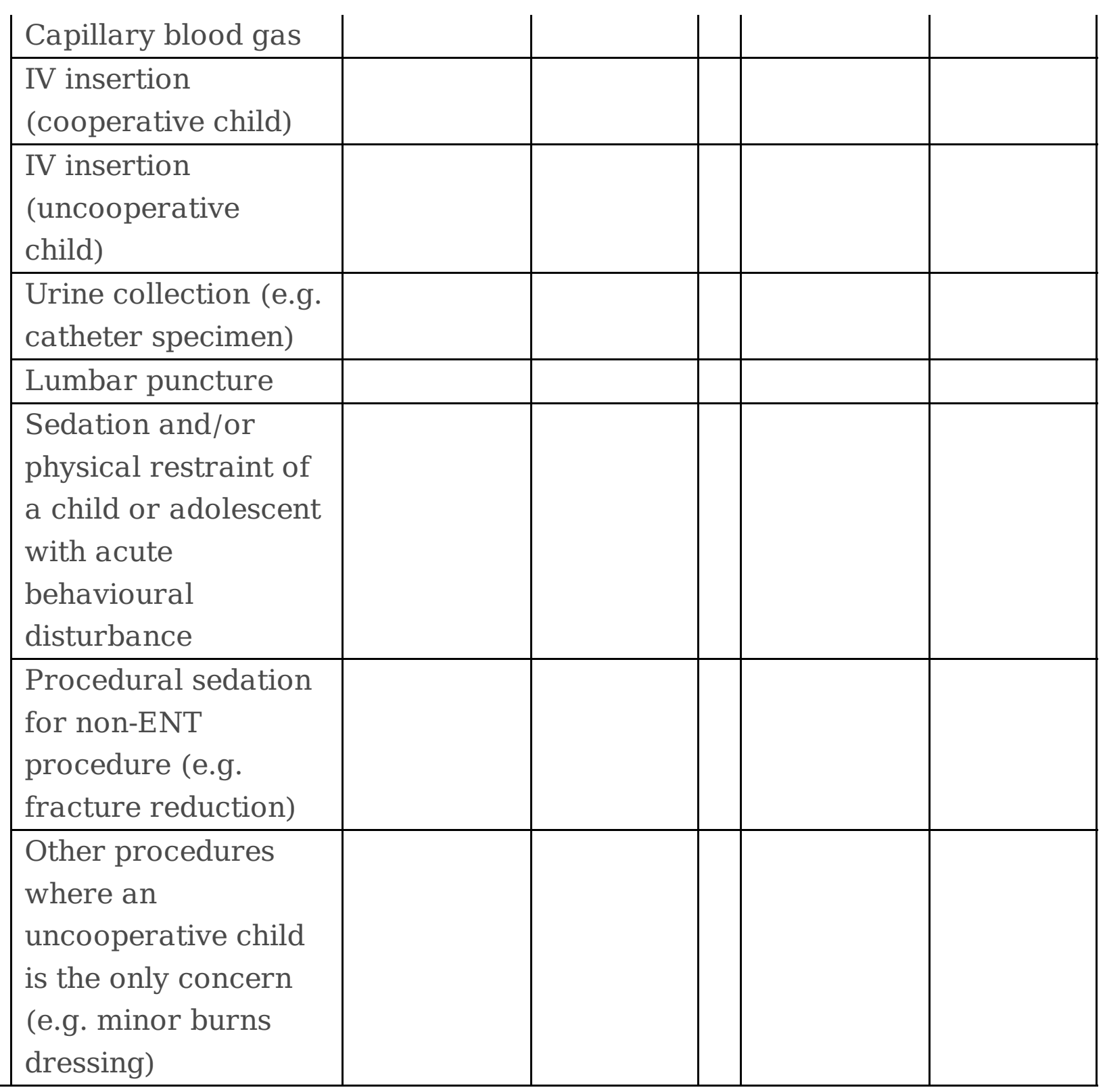

Key:

\begin{tabular}{|l|l|l|l|}
\hline & Airborne PPE (consensus) & & Standard precautions (consensus) \\
\hline & Airborne PPE (low consensus) & & Standard precautions (low consensus) \\
\hline & Droplet PPE (consensus) & & No consensus \\
\hline & Droplet PPE (low consensus) & & Two equal recommendations \\
\hline
\end{tabular}

Table 4. Expert group PPE recommendations for resuscitation / respiratory support: possible future situation with high levels of community transmission 


\begin{tabular}{|c|c|c|c|c|}
\hline & \multicolumn{2}{|c|}{$\begin{array}{l}\text { Child with respiratory } \\
\text { symptoms or fever }\end{array}$} & \multicolumn{2}{|c|}{$\begin{array}{l}\text { Child with no respiratory } \\
\text { symptoms and no fever }\end{array}$} \\
\hline & Emergency & $\begin{array}{l}\text { Infectious } \\
\text { diseases }\end{array}$ & Emergency & $\begin{array}{l}\text { Infectious } \\
\text { diseases }\end{array}$ \\
\hline $\begin{array}{l}\text { Cardiopulmonary } \\
\text { resuscitation }\end{array}$ & & & & \\
\hline Bag-mask ventilation & & & & \\
\hline $\begin{array}{l}\text { Intubation and related } \\
\text { procedures }\end{array}$ & & & & \\
\hline Tracheostomy procedures & & & & \\
\hline Nebuliser therapy & & & & \\
\hline $\begin{array}{l}\text { High-flow nasal oxygen } \\
\text { therapy }\end{array}$ & & & & \\
\hline $\begin{array}{l}\text { Non-invasive ventilation } \\
\text { (CPAP or BiPAP) }\end{array}$ & & & & \\
\hline Suctioning & & & & \\
\hline Extubation & & & & \\
\hline
\end{tabular}

Key:

\begin{tabular}{|c|c|}
\hline Airborne PPE (consensus) & Standard precautions (consensus) \\
\hline Airborne PPE (low consensus) & Standard precautions (low consensus) \\
\hline Droplet PPE (consensus) & No consensus \\
\hline Droplet PPE (low consensus) & Two equal recommendations \\
\hline
\end{tabular}

Table 5. Expert group PPE recommendations for other procedures involving the head / neck / airway, and other paediatric emergency: possible future situation with high levels of community transmission 


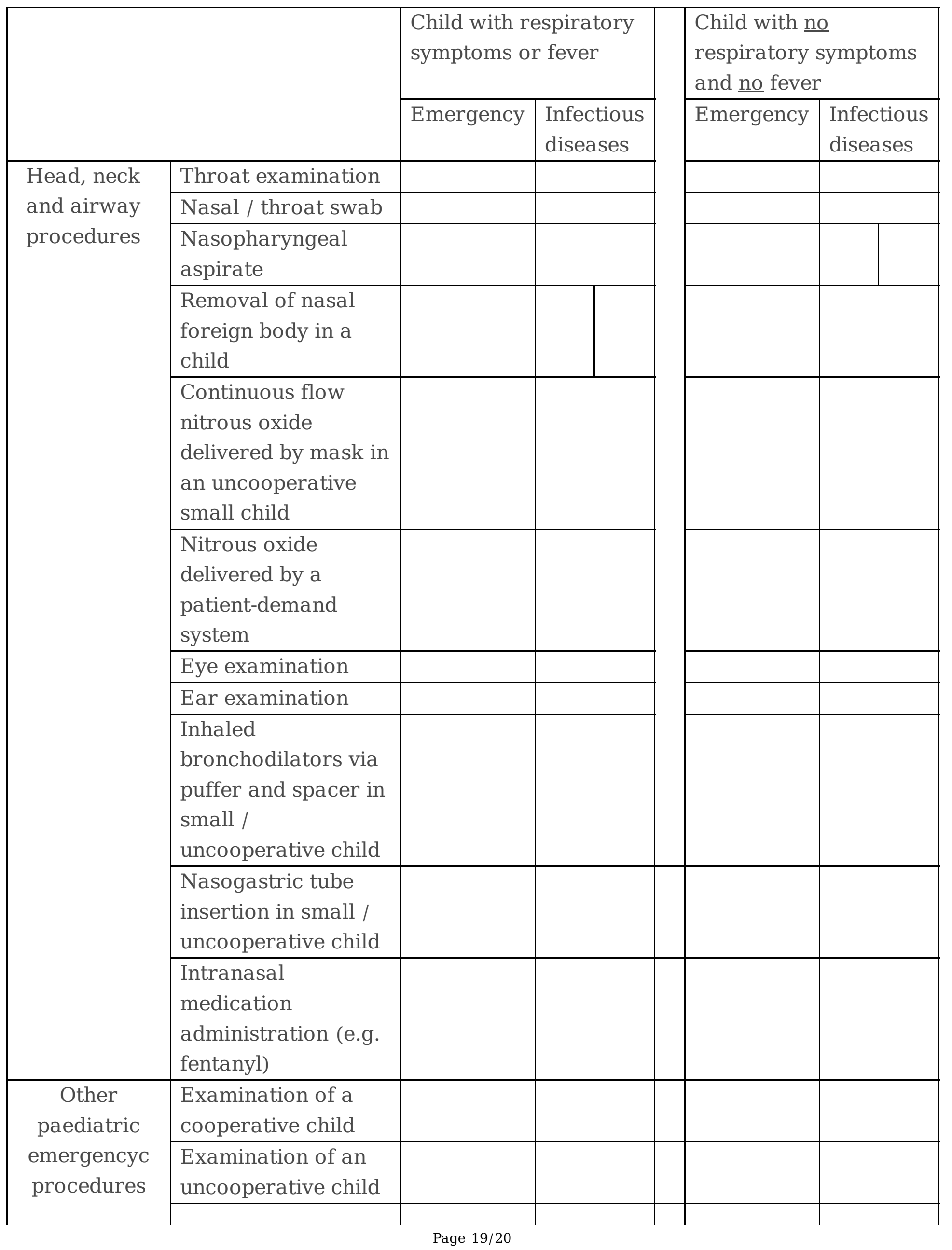




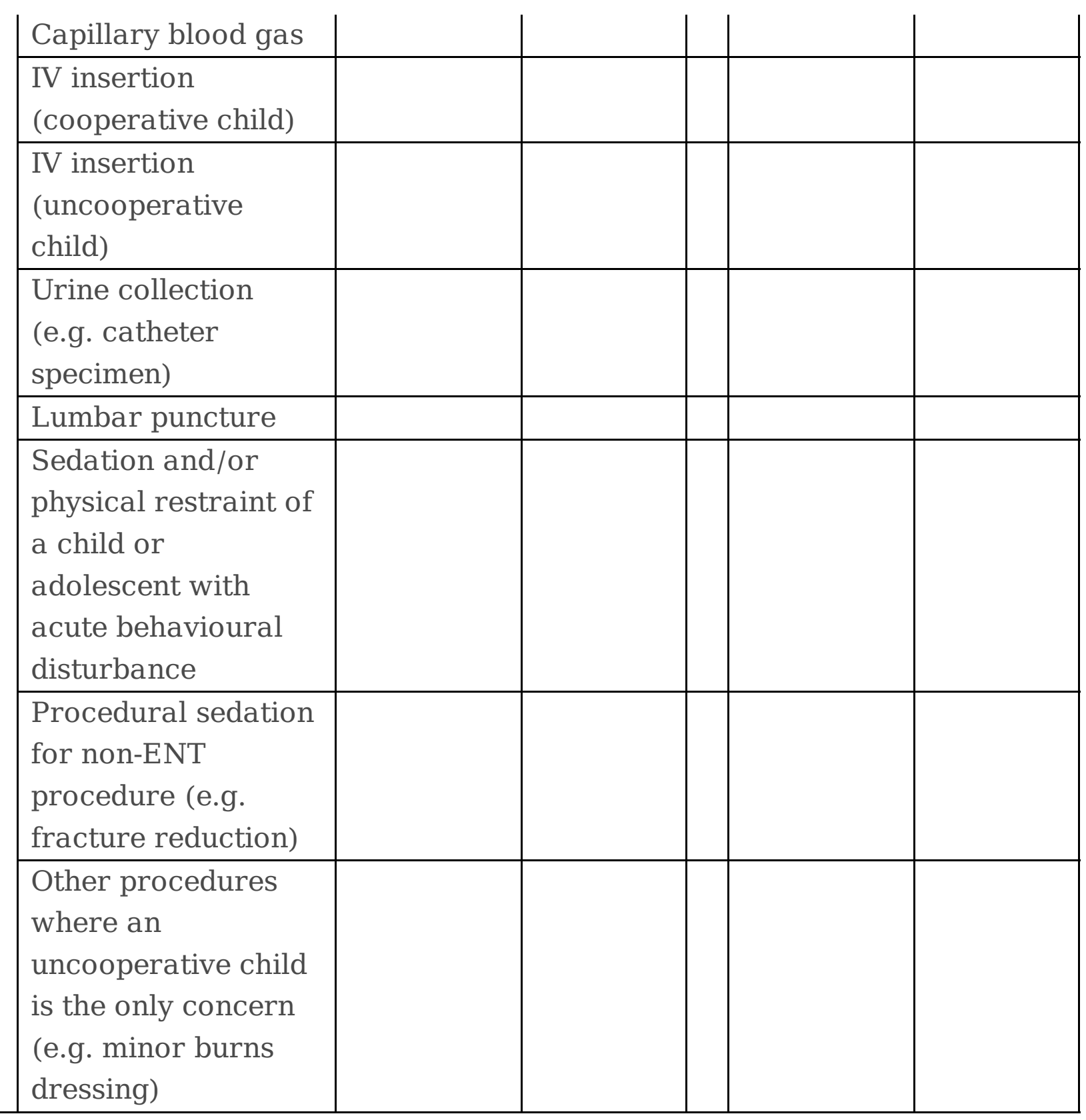

Key:

\begin{tabular}{|l|l|l|l|}
\hline & Airborne PPE (consensus) & & Standard precautions (consensus) \\
\hline & Airborne PPE (low consensus) & & Standard precautions (low consensus) \\
\hline & Droplet PPE (consensus) & & No consensus \\
\hline & Droplet PPE (low consensus) & & Two equal recommendations \\
\hline
\end{tabular}

